\title{
STATUS GIZI, PERILAKU DAN KEBIASAAN SARAPAN PAGI TERHADAP PRESTASI BELAJAR SISWA MADRASAH IBTIDAIYAH AHMAD DENAN BANJARMASIN TAHUN 2018
}

nutrition Status, Behavior and Happiness Habits on Learning Achievement of Madrasah Ibtidaiyah Students, Ahmad Denan Banjarmasin in 2018

Khairul Anam , Fakhsiannor

Fakultas Kesehatan Masyarakat UNISKA, Banjarmasin

Email : khairul.anam96@ymail.com

\begin{abstract}
Ibtidaiyah Madrasah Ahmad Denan Banjarmasin, after survey researchers, the results of students still have poor nutritional status. The study sample numbered 37 students, this study was conducted for two months, namely in May and June 2018, data collection was carried out through measurement of body weight, height, interview and questionnaire, data analysis was carried out by Univariate Analysis. The results showed poor nutritional status of $86.49 \%$, normal nutritional status of $13.51 \%$, behavior and breakfast habits most of the time breakfast was $54.06 \%$, learning achievement was mostly in the category of $54.05 \%$.
\end{abstract}

Keywords : Determinant, Dental Caries Incidence, Age 18-40 Years

\begin{abstract}
Abstrak
Madrasah Ibtidaiyah Ahmad Denan Banjarmasin, setelah peneliti survey, hasilnya siswa masih memiliki status gizi kurang. Sampel penelitian berjumlah 37 orang Siswa, Penelitian ini dilakukan selam dua bulan yaitu bulan Mei dan Juni 2018, Pengumpulan data dilakukan melalui Pengukuran berat badan, tinggi badan, Wawancara dan kuesioner, analisa data dilakukan dengan Analisis Univariat. Hasil penelitian menunjukan Status Gizi kurang 86,49\%, Status Gizi Normal 13,51\%, Perilaku dan kebiasaan sarapan pagi sebagian besar kadang-kadang sarapan pagi yaitu 54,06\%, prestasi belajar sebagian besar pada kategori cukup 54,05\%. Kata Kunci: Status Gizi; Perilaku Kebiasaan Sarapan Pagi; Prestasi Belajar.
\end{abstract}

Kata Kunci : Gizi, Sarapan, Siswa 


\section{PENDAHULUAN}

Masalah kesehatan dan gizi anak usia sekolah yaitu 6-12 tahun, termasuk golongan masyarakat yang disebut kelompok rentan gizi. Pada saat ini mereka sedang mengalami proses pertumbuhan yang relatif pesat dan memerlukan asupan gizi dalam jumlah yang relatif besar. Untuk itu kesehatan yang baik ditunjang oleh keadaan gizi yang baik merupakan hal yang utama untuk tumbuh kembang yang optimal bagi seorang anak. Kondisi ini hanya dapat dicapai melalui proses pendidikan dan pembiasaan serta penyediaan kebutuhan yang sesuai (Santoso, 2004).

Tumbuh kembang anak usia sekolah dan pemberian nutrisi dengan kualitas dan kuantitas yang baik serta benar dalam masa tumbuh kembang tersebut perlu pemberian nutrisi atau asupan makanan pada anak tidak selalu dapat dilaksanakan dengan sempurna. Sering tirnbul masalah terutama dalam pemberian makanan yang tidak benar dan menyimpang. Penyimpangan ini mengakibatkan gangguan pada banyak organ-organ dan sistem tubuh anak (Judarwanto, 2011).

Survey Depkes tahun (1997) terhadap 600 ribu anak SD di 27 propinsi di Indonesia menujukkan bahwa anak sekolah yang mengalami gangguan masalah gizi kurang berkisar antara 13,6 - 43,7\%. Masalah kekurangan gizi pada usia SD terlihat dengan prevalensi kekurangan energi protein di Indonesia pada siswa SD sebesar 30,1\%. Sedangkan prevalensi anemia besi mencakup sekitar $25-40 \%$. Besarnya prevalensi gangguan pertumbuhan pada siswa SD di Indonesia sebesar 32\% di pedesaan dan 18\% di wilayah Perkotaan (Soekirman, 2000).

Ada sejumlah bukti tentang efek lapar jangka pendek pada fungsi kognitif dan perilaku yang bersumber dari penelitian tentang menyediakan atau tidak menyediakan sarapan. Beberapa penelitian mengenai pemberian makanan disekolah juga memberikan informasi tentang efek penyediaan makanan terhadap prestasi belajar, perilaku dalam kelas, angka kehadiran dan gizi. Beberapa penelitian telah diselenggarakan baik di negara maju maupun negara berkembang (Gibney, et al., 2009).
Sekolah Dasar (SD) adalah jenjang paling dasar pada pendidikan formal di Indonesia. Sekolah dasar dilaksanakan dalam waktu 6 tahun, mulai dari kelas 1 sampai kelas 6. Siswa kelas 6 diwajibkan untuk mengikuti Ujian Nasional yang rnempengaruhi kelulusan atau tidaknya siswa. Lulusan sekolah dapat melanjutkan pendidikan ke Sekolah Menengah Pertama (SMP) atau yang sederajat. Pelajar sekolah dasar umurnya berusia 712 tahun. Di Indonesia, setiap warga negara berusia 7-15 tahun wajib mengikuti pendidikan dasar 9 tahun. yakni sekolah dasar 6 tahun dan Sekolah Menengah Pertama 3 tahun (Lenterak, 2O11).

Jumlah Seluruh Madrasah Ibtidaiyah di Kota Banjarmasin terdapat 62 Madrasah Ibtidaiyah, dan salah satunya adalah Madrasah Ibtidaiyah Ahmad Denan yang terletak di tengah Kota Banjarmasin, Setelah Peneliti melakukan Survey masih memiliki status gizi kurang, dan setelah dilakukan penelitian melihat masih ada sebagian siswa berperilaku tidak membiasakan sarapan pagi malahan sering makan makanan yang tidak memiliki asupan gizi yang baik seperti gula-gula, mengabaikan sarapan pagi mengakibatkan tubuh tidak mendapatkan asupan gizi yang cukup, sehingga menurunkan status gizi dan akan mempengaruhi terhadap prestasi belajar. Dari hal tersebut maka peneliti tertarik melakukan penelitian status gizi, perilaku dan kebiasaan sarapan pagi terhadap prestasi belajar siswa Madrasah Ibtidaiyah Ahmad Denan Banjarmasin 2018.

\section{BAHAN DAN METODE}

Penelitian ini merupakan penelitian yang bersifat observasi, yaitu penelitian yang dilakukan untuk mempelajari korelasi yang dilakukan dengan cara pendekatan observasi atau pengumpulan data pada satu saat. Data yang menunjukan titik waktu tertentu atau pengumpulannya dilakukan dalam waktu bersamaan pada subjek penelitian. Populasi penelitian adalah seluruh siswa kelas 3 dan kelas 4 siswa Madrasah Ibtidaiyah Ahmad Denan Tahun Pelajaran 2017/2018 Banjarmasin yang berjumlah 37 Siswa. Sampel dalam penelitian ini ditentukan dengan total populasi. Analisis data dilakukan secara univariat. 


\section{HASIL DAN PEMBAHASAN}

Analisis univariat dilakukan untuk mendiskripsikan tiap variabel yang diukur dalam penelitian ini yang meliputi status gizi, perilaku dan kebiasaan sarapan pagi, serta prestasi belajar siswa.

Tabel 1. Tabel Distribusi Frekuensi Variabel Penelitian.

\begin{tabular}{|c|c|c|}
\hline Variabel & $\mathbf{N}$ & $\%$ \\
\hline \multicolumn{3}{|l|}{ Status Gizi } \\
\hline Kurang & 32 & 86,49 \\
\hline Normal & 5 & 13,51 \\
\hline Lebih & 0 & 0 \\
\hline \multicolumn{3}{|c|}{ Kebiasaan Sarapan Pagi } \\
\hline Sering & 9 & 24,32 \\
\hline Kadang-kadang & 20 & 54,06 \\
\hline Tidak Sarapan & 8 & 21,62 \\
\hline \multicolumn{3}{|l|}{ Prestasi Belajar } \\
\hline Baik & 17 & 45,95 \\
\hline Cukup & 20 & 54,05 \\
\hline Jumlah & 37 & 100 \\
\hline
\end{tabular}

Dari hasil penelitian ini dapat diketahui bahwa sebagian besar siswa Madrasah Ibtidaiyah Ahmad Denan Banjarmasin memiliki status gizi kurang. Sebanyak 32 siswa (86,49\%). Hal ini menunjukan bahwa status gizi siswa Madrasah Ibtidaiyah Ahmad Denan Banjarmasin pada umumnya bisa dikategorikan status gizi kurang. Status gizi adalah suatu keadaan keseimbangan antara asupan (intake) dan kebutuhan (requerement) zat gizi sesuai dengan yang dibutuhkan. Status gizi tidak seimbang dapat dipresentasikan dalam bentuk gizi kurang yaitu jumlah asuoan gizi dari yang dibutuhkan oleh tubuh, sedangkan status gizi lebih bila asupan zat gizi melebihi dari yang dibutuhkan (Supariasa, 2001).

Berdasarkan dari hasil penelitian ini siswa yang memiliki status gizi kurang ada 32 siswa $(86,49 \%)$ responden. Hal ini sangat perlu mendapat perhatian yang khusus, karena status gizi yang kurang pada anak dapat menyebabkan kesehatan. Status gizi kurang disebabkan oleh berbagai faktor, antara lain kebiasaan sarapan pagi, pola makan, kebiasaan jajan, ataupun faktor lain seperti infeksi (Mardiansyah, 2008)

Hal ini sesuai dengan siswa yang berstatus gizi kurang perlu mendapat perhatian khusus, dan usaha perbaikan gizi perlu ditingkatkan agar pertumbuhan dan perkembangan anak dapat berjalan secara optimal sesuai dengan bertambahnya usia, bahwa anak sekolah yang mengalami masalah gizi kurang akan menyebabkan anak tersebut terganggu motivasinya untuk belajar, kemampuan untuk berkonsentrasi dan kesanggupan untuk belajar, seorang anak yang kurang gizi akan tidak tanggap terhadap lingkungan (Alan Breg, 1986). Untuk meningkatkan perbaikan gizi, status gizi baik atau status gizi optimal terjadi bila tubuh memperoleh cukup zat-zat yang digunakan secara efisien, sehingga memungkinkan pertumbuhan fisik, pertumbuhan otak, kemampuan kerja dan kesehatan secara umum pada tingkat setinggi mungkin (Supariasa, 2001).

Hasil Penelitian Darmawan Tahun 2012, judul penelitian Gambaran Status Gizi anak Sekolah Dasar Eks. Transmigrasi dan penduduk lokal di kecamatan pelayanan kabupaten Sarolangon Provinsi Jambi, Hasil Penelitian adalah berdasarkan IMT Status Gizi Normal 76 Siswa (83,52\%) dari 91 Siswa yang di teliti. Sementara Hasil Penelitian Gambaran Status Gizi Siswa Madrasah Ibtidaiyah Ahmad Denan Banjarmasin Tahun 2018 adalah berdasarkan IMT Status Gizi Normal 5 Siswa $(13,51 \%)$ dari 37 Siswa yang di teliti, ini di karenakan oleh konsumsi makanan yang kalorinya dan proteinnya rendah karena kemiskinan indikatornya adalah taraf ekonomi keluarga hubungannya dengan daya beli dan pekerjaan untuk menunjang kehidupan keluarga.

Bagi anak sekolah, meninggalkan sarapan pagi membawa dampak yang kurang menguntungkan. Hal ini sesuai dengan hasil penelitian ini yang dominan yaitu kadang-kadang sarapan pagi sebelum berangkat sekolah, sehingga konsentrasi di kelas bisa buyar karena tubuh tidak memperoleh masukan gizi yang cukup. Sebagai gantinya, anak jajan di sekolah untuk sekedar mengganjal perut. Tetapi mutu dan keseimbangan gizi jadi tidak seimbang. Oleh karena itu kebiasaan sarapan hendaknya dipertahankan dalam setiap keluarga (Hosman, 2002).

Kebiasaan sarapan pagi sangat bermanfaat bagi setiap orang. Bagi orang dengan sarapan pagi 
dapat memelihara keadaan fisik, mempertahankan daya tahan dan dapat meningkatkan kecerdasan belajar menjadi lebih baik. Kebiasaan sarapan pagi juga membantu seseorang untuk memenuhi gizinya sehari-hari (Direktorat Bina Gizi Masyarakat, 1995).

Pada saat sarapan pagi biasakan anak ditemani oleh anggota keluarga baik ayah atau ibu maupun anggota keluarga lainnya. Untuk membiasakan anak-anak yang belum terbiasa sarapan pagi perlu memakai cara bertahap. Mulamula diberikan sarapan pagi dengan takaran atau porsi sedikit, kemudian secara bertahap, porsi makanan ditambah sesuai anjuran. Orang tua dan guru hendaknya selalu mengingatkan anak untuk selalu sarapan pagi dan memberikan penjelasan mengenai sarapan pagi. Bagi anak yang tidak sempat sarapan pagi, sebaiknya makanan dibawa kesekolah (Depkes RI, 2002).

Hasil Penelitian Sukiniarti Tahun 2013, judul penelitian kebiasaan makan pagi pada anak usia SD dan hubungan dengan tingkat kesehatan dan prestasi belajar di wilayah kelurahan pondok benda, hasil penelitian adalah $(89,66 \%)$ anak setiap pagi selalu makan pagi sebelum berangkat sekolah, sementara hasil penelitian Perilaku dan kebiasaan Sarapan Pagi Siswa Madrasah Ibtidaiyah Ahmad Denan Banjarmasin Tahun 2018, hasil penelitian adalah kadang-Kadang sarapan pagi $(54,06 \%)$, jadi yang dominan adalah Kadang-Kadang Sarapan Pagi sebelum berangkat ini di karenakan siswa mempunyai uang saku dan selalu jajan di sekolah, jajanan yang di konsumsi gula-gula, chiko, agar-agar yang proteinnya rendah.

Salah satu faktor yang menjadikan siswa berprestasi baik yaitu faktor minat. Minat adalah kecenderungan yang mantap dalam subyek untuk merasa tertarik pada bidang tertentu. Siswa yang kurang berminat dalam pelajaran tertentu akan menghambat dalam belajar, Selain itu peran guru dalam mengolah pelajaran menjadi sebuah sajian yang menarik juga sangat diperlukan.

Untuk membuat prestasi belajar siswa lebih baik selain minat di perlukan faktor intelegensi untuk mencapai prestasi disekolah yang di dalamnya berpikir perasaan, intelegensi memegang peranan penting bagi prestasi belajar siswa, faktor guru sebagai tenaga pendidikan memiliki tugas menyelenggarakan kegiatan belajar mengajar, membimbing, melatih, mengolah, meneliti dan mengembangkan serta memberikan teknik karena itu setiap guru harus memiliki wewenang dan kemampuan, kepribadian dan profesional, faktor lingkungan keluarga turut mempengaruhi kemampuan hasil kerja, karena sebagian besar waktu belajar dilaksanakan dirumah, faktor sumber-sumber belajar salah satu faktor yang menunjang keberhasilan dalam proses belajar adalah tersedianya sumber belajar yang memada. Sumber belajar itu dapat berupa media/alat bantu belajar serta bahan baku belajar dapat digunakan untuk membantu dalam melakukan kegiatan belajar, maka pelajaran akan lebih menarik dan menjadi konkret, mudah dipahami

Hasil Penelitian Gesti Alfiah Tahun 2012, judul penelitian Gambaran Kecerdasan Emosional dan Prestasi Belajar pada siswa negeri XI Manado, hasil penelitian adalah kecerdasan emosional siswa sedang dan rata-rata Prestasi Belajar sedang, sementara hasil penelitian Gambaran Prestasi Belajar siswa Madrasah Ibtidaiyah Ahmad Denan Banjarmasin Tahun 2018, hasil penelitian adalah Prestasi Belajar Baik (45,95\%) dan Prestasi Belajar Cukup (54,05\%), ini yang dominan adalah Prestasi Belajar Cukup (54,05\%) di karenakan oleh faktor internal yang berasal dari dalam diri siswa baik aspek fisiologis maupun aspek phikologis dan faktor eksternal yang berasal dari luar diri siswa, baik faktor guru, faktor lingkungan keluarga dan faktor yang menunjang keberhasilan dalam proses belajar.

\section{KESIMPULAN}

Status Gizi siswa Madrasah Ibtidaiyah Ahmad Denan Banjarmasin Tahun 2018, berdasarkan Indeks Massa Tumbuh (IMT) Status Gizi Kurang 32 siswa (86,49\%). Perilaku Kebiasaan Sarapan pagi Siswa Madrasah Ibtidaiyah Ahmad Denan Banjarmasin Tahun 2018, diperoleh hasil yang paling terbayak menyatakan kadang-kadang sarapan pagi 20 siswa (54,06\%). Prestasi Belajar siswa Madrasah Ibtidaiyah Ahmad Denan Banjarmasin Tahun 2018, memperoleh hasil prestasi belajar Cukup 20 siswa (54,05\%). Perlu adanya pendidikan kesehatan yang 
berhubungan dengan status gizi dan sarapan pagi sehingga siswa dapat memahami keadaan yang dialaminya, pengenalan gizi seimbang dan memberikan arahan kepada siswa untuk membiasakan sarapan pagi sebelum berangkat sekolah sehingga akan berpengaruh dengan prestasi belajar.

\section{DAFTAR PUSTAKA}

Chaedar, 2002. Meningkatkan Prestasi Belajar Anak. Bandung:Remaja Rosda

Departemen Gizi dan Kesehatan Masyarakat.2011. Gizi dan Kesehatan Masyarakat. jakarta : Raja grafindo Persada.

Depkes RI, 1995. Pedoman Kerja Tenaga Gizi Puskesmas. Dirjen Bina Gizi Masyarakat -----, 2003. Definisi Operasional Status gizi.

Gibney, Michael j, 2009 . Gizi Kesehatan Masyarakat. Jakarta : EGC.
Notoatmodjo, S. 2003. Metodologi Penelitian Kesehatan. Jakarta: Rineka Cipta. 2010. Metodologi Penelitian Kesehatan. Jakarta: Rineka Cipta.

O,dea,Jenny. 2005. Makan Sehat Anak Cerdas. Jakarta: Bhuana Ilmu Populer.

Program wajib belajar 2000. Definisi Operasional Prestasi belajar.

Riyanto, A. 2011. Pengolahan dan Analisis Data Kesehatan. Yogyakarta : Nuha Medika.

Santoso, Soegeng. 2004 Kesehatan dan Gizi. Jakarta : Asdi Mahasatya

Sugiyono, 2005 . Metode Penelitian Administrasi. Bandung: Alfabeta.

Supariasa, Dewa Nyoman. 2001. Penelitian Status Gizi.takatta: EGC.

Wiharyani, 2006. Definisi Operasional Kebiasaan sarapan pagi

Yayuk F. Baliwati, dkk. 2004. Pangan gizi dan Pertanian. Jakarta : Universitas Indonesia. 